\title{
DESIGN CHARACTERISTICS OF THE SHORT VERSION EI-DARL-V1 OF ORIGINAL EMOTIONAL INTELLIGENCE MEASUREMENT TECHNIQUE
}

\author{
Dalia Antinienė, Rosita Lekavičienė \\ Kaunas University of Technology, Kaunas, Lithuania
}

\begin{abstract}
Research background and hypothesis. In the absence of unanimous definition of emotional intelligence (EI), it is reasonable to integrate various concepts of this construct when constructing the new original EI research methodology. Therefore, a decision was made to provide the tasks in various ways, i. e. not only in the form of items, but also providing face mimic identification and emotional-social and interpersonal situation solution assignments, which would cover a larger part of the research phenomenon.

Research aim was to present the short version of the created EI measurement technique - EI-DARL-V1 - based on the best practices of foreign scientists by identifying the problems of the construction methodology and providing psychometric characteristics.

Research methods. While constructing EI measurement technique, the two following blocks of tasks were prepared: 1) the block of tasks that defines EI as a personality trait; 2) the block of tasks that define EI as a cognitive (ability) characteristic. 119 items were generated for the version EI-DARL-V1. The study data were collected in 2012-2013 from 1430 subjects (experimental group consisted of 1400 subjects and control-contrast (i. e. older age) group consisted of 30 subjects) in different regions in Lithuania. Subjects' age of the main (experimental) sample was 19.7 years $(\mathrm{SD}=3.29)$.

Research results. The created EI measurement technique EI-DARL has two forms - the short (EI-DARL-V1) and the long (EI-DARL-V2) ones. The short version, presented in this article, consists of five scales ("Understanding your emotions", "Your emotional control", "Understanding emotions of the other person", "Control of other emotions", "Manipulations"), a 73-item questionnaire, where subjects reveal their degree of agreement with the items.

Discussion and conclusions. The psychometric quality characteristics of the measurement technique subscales meet the requirements: Cronbach's alpha coefficient values fluctuate from 0.73 to 0.89 ; the average inter-correlation among the measurement technique items is from 0.29 to 0.49 ; $\mathrm{i} / \mathrm{tt}$ (resolution) indicators often exceed 0.5 ; the instrument has only those items, the factorial loadings exceed 0.3 ; factor's overall explained dispersion ranges from 22 to $46 \%$; KMO values range from 0.88 to 0.94 . EI-DARL-V1 validity and reliability conditions are met.
\end{abstract}

Keywords: emotional intelligence, psychometrics, validity, reliability.

\section{INTRODUCTION}

$\mathrm{E}$ motional intelligence (EI) measurement is a manifold topic. Firstly, the sceptical attitude towards EI measurement possibilities in the academic community is strengthened by the fact that there is no common agreement on how the EI construct should be determined. Secondly, EI is a latent construct which cannot be observed directly, thus the methodology validity issue becomes really acute. Thirdly, in general there is a fairly sceptical view of the accuracy of the psychometric and statistical methods, their declared capabilities (Brody, 2004). Fourthly, authors themselves make significantmistakes when constructing methodology (Schmidt, Hunter, 1999; Hunsley, Meyer, 2003; 
Borsboom, 2005). This list of problems could be extended even more (detailed analysis of the issue is presented in the article of R. Lekavičiene and D. Antinienè called "Emotional intelligence: measurement problems and opportunities", 2013). On the other hand, it is generally recognised that the key to personal satisfaction with life is the understanding of your own and others' emotions, their management. And on the contrary - emotional illiteracy makes the personality stumble along the way, experience frustration, misunderstandings, twitching relationships. Scientific understanding of EI, the development of measurement methodologies would let to create training programs for emotional skills, which would help to make life more full and productive (Sternberg, Grigorenko, 2007; Schutte, Malouff, 2012). It is this scientific problem that influenced the authors to contribute to the challenges of taking up a challenging task - the original EI measurement methodology development.

The purpose of this article was to introduce the short version EI-DARL-V1 of the original EI measurement technique by revealing its design process. Objectives: 1) introduce the construction logics and the structural parts of the measurement technique; 2) to provide psychometric statistics of this measurement technique.

\section{RESEARCH METHODS}

Methodology. Two task blocks were prepared while constructing the measurement technique: 1) EI is treated as a personality trait; 2) EI is defined as a cognitive (ability) characteristic. The methodological problems of the development of the first block and psychometric characteristics will be discussed in the result section.

Subjects. EI research respondents were selected to a sample by quota sampling method, while maintaining the natural proportions of the general population in Lithuania. In total 1430 subjects were questioned, 1400 of which were young people, living in various Lithuanian regions, studying, employed, unemployed and even sentenced in prison; 30 subjects were assigned to controlcontrast group, their age ranging from 28 to 51 years. The study covered the geography of Vilnius, Kaunas, Klaipėda, Šiauliai, Telšiai, Panevėžys, Utena, Marijampolè, Kaišiadorys, Alytus. The age of the main sample $(\mathrm{n}=1400)$ subjects was from 17 to 27 years $(\mathrm{M}=19.7, \mathrm{SD}=3.29)$. The study included $43.8 \%$ of men and $56.2 \%$ of women. The largest part of the measurement technique subjects were pupils (56.7\%) and students (35.2\%), the remaining part of subjects consisted of employed, un-employed and engaged in other activities. To sum up the characteristics of the study sample, it can be stated that according to the nature of the study (non-experimental correlation study) and a variety of outlets, the sample size and the compliance of the socio-demographic characteristics with the statistical indicators of population, the sample can be seen as relatively presentable and satisfying the requirements of the study.

Stages of the study. In the first stage, a pilot test on 30 subjects was conducted. Some statements had been revised in order to avoid ambiguity in understanding. In the second stage, graphically attractive form of a comprehensive three-part EI questionnaire and the test of Social Competence were prepared. In the third stage, a study, which included 1430 subjects, was carried out. The data were collected in 2012 fall - 2013 spring. In the fourth stage, five-six weeks later, a re-test with 50 subjects was conducted. In the fifth stage, a statistical processing of the part of the data obtained was performed (2013 autumn).

Methods of mathematical statistics. Data analysis was conducted using SPSS 17.0 statistical package for data processing. We applied descriptive and mathematical statistics methods $-\mathrm{a}$ multi-factor analysis was conducted by using the VARIMAX orthogonal rotation, Cronbach's alpha coefficients were calculated, ANOVA analysis was used, Spearman's and Pearson's correlation coefficients were calculated, Wilcoxon signed rank test, split-half method and others were used.

\section{RESEARCH RESULTS}

The prepared measurement technique has two versions - the short (EI-DARL-V1) and the long (EI-DARL-V2). This article will introduce the short version of EI-DARL-V1. It consists of a traditional questionnaire, where the subjects reveal their degree of consent with the items (evaluations were performed on a six-point Likert scale). During the time of the measurement technique development (in the initial version) it was hypothetically aimed at a five scale measurement technique: the perception of one's own emotions, perception of others' emotions, management/control of one's own emotions and behaviour, management/control of interpersonal relations. The aforesaid scales reflected the fundamental, from the researchers' point of view, dimensions of the emotional 
intelligence. These scales were complemented by a hypothetical fifth - manipulation - scale. The items of the manipulation scale were designed to grope the person's ability to control the behaviour of people around them by using their emotions, discovering their weaknesses. The scale scores of manipulative behaviour that reflected a person's ability to control the other person's feelings provided an opportunity to see a more detailed psychological portrait of the subject. As many as 119 items were generated in the original version.

By using the original factorial validation $(\mathrm{n}=$ 1430), the items which subverted the factor analysis model were eliminated. The remaining 73 items were compacted into nine sub-scales named in the following working titles: 1) "Causal understanding of your own emotions" (Sometimes I feel very sad, but I do not know why (-)); 2) "Understanding of your own emotions" (Usually I have a good understanding of why I am experiencing specific feelings); 3) "Transforming your negative emotions into positive" (I know very well what to do to brighten up my mood); 4) "Self-control/Suppressed expression of emotions" (I am good at controlling myself even when it seems that the patience is lost); 5 ) "The control of your negative emotions" (I am good at controlling myself even when it seems that the patience is lost); 6) "Perception of other's emotion" (I always recognise my friends' emotions based on their behaviour); 7) "Regulation of other's emotion" (I know how to encourage a person who is in a difficult situation); 8) "Selfish influence on others' emotions or behaviour" (I am capable of finding a sensitive chord in a person and using that); 9) "The ability to cause other people's negative emotions" (If necessary, I would know how to make fun of other people knowing that it would hurt badly).
Psychometric quality characteristics of the EI diagnostic conduct have been calculated: 1) Cronbach's alpha coefficient value fluctuates from 0.73 to fairly high values, i. e. $0.89 ; 2$ ) the average correlation among the items of the measurement technique is from 0.29 to 0.49 ; 3 ) $\mathrm{i} / \mathrm{tt}$ - resolution rates - often exceed 0.5 , which indicates that the items of measurement technique pretty accurately differentiate the subjects according to certain properties; 4) $\mathrm{L}$ - factorial loadings: the instrument is left with only those items, whose factorial loadings exceed 0.3 ; 5) factor's overall explained dispersion fluctuates from 22 to $46 \%$; 6) $\mathrm{KMO}$ values range from 0.88 to 0.94 . In conclusion, the psychometric quality of the measurement technique is sufficient.

The aforesaid sub-scales were multiplexed into five wider scales by using secondary factor analysis: "The causal understanding of emotions" and "Emotion perception" sub-scales into the scale of "Emotion perception"; "Transforming your negative emotions into positive", "Self-control/ Suppressed expression of emotions" and "The control of your negative emotions" into the scale of "The control of your emotions"; "Selfish influence on others" emotions or behaviour" and "The ability to cause other people's negative emotions" into the scale of "Manipulation". The remaining two scales "Perception of other's emotion" and "Regulation of other's emotion" remained the same as they were obtained in the initial factor analysis.

In order to determine the psychometric appropriateness of the EI measurement technique, the internal consistency of the total scale and other parameters of EI-DARL-V1 measurement technique were checked. The obtained data is shown in the Table 1.

\begin{tabular}{|l|c|c|c|c|c|}
\hline \multicolumn{1}{|c|}{ Scale name } & Cronbach's $\alpha$ & $\mathbf{i} / \mathbf{t t}$ & $\begin{array}{c}\text { Average } \\
\text { inter-correlation } \\
\text { among items }\end{array}$ & $\begin{array}{c}\text { Minimum } \\
\text { inter-correlation } \\
\text { among items }\end{array}$ & $\begin{array}{c}\text { Maximum } \\
\text { inter-correlation } \\
\text { among items }\end{array}$ \\
\hline $\begin{array}{l}\text { "The understanding of } \\
\text { your own emotions" }\end{array}$ & 0.87 & 0.40 & 0.35 & 0.16 & 0.60 \\
\hline $\begin{array}{l}\text { "The control of your } \\
\text { own emotions" }\end{array}$ & 0.91 & 0.36 & 0.27 & 0.06 & 0.53 \\
\hline $\begin{array}{l}\text { "The understanding of } \\
\text { other emotions" }\end{array}$ & 0.89 & 0.54 & 0.36 & 0.23 & 0.53 \\
\hline "The control of other \\
emotions"
\end{tabular}


In order to get a clearer and more defined structure of the EI characteristics, a tertiary factor analysis was performed with scale scores. The data of the analysis allows us to speak about the threedimensional structure of emotional intelligence: The understanding and control of your own emotions (overall explained dispersion 35.7\%), The understanding and control of other emotions (20.6\%) and Manipulation factors (19.0\%) were distinguished. The entire three-factor model explains $75.3 \%$ of the sampled features scatter, KMO index reaches 0.73 . Thus, the relevance of data of the factor analysis is sufficient. Dispersion, explained by individual factors is not high, but it is tolerable in psychometric studies. The factor weights obtained in the model are high, $0.71 \leq \mathrm{r}$ $\leq 0.92$, suggesting that the created categories are relevant since they meet the construct validity methodological norm, which is generally acceptable in the diagnostic research. The variables, segregated in each of the three factors, are easy to interpret, thus it can be stated, that the model is statistically significant and theoretically valid.

Criteria validity of EI-DARL-V1 was checked on the ground of Social Competence Test adapted by R. Lekavičienė (Lekavičienè, 2001; Lekavičienè, Antinienè, 2013). Subjects of EI research also had to evaluate the questions of the latter test. Analysis of variance (ANOVA) was selected for the verification. After selecting a significance level $\alpha=0.01, p \leq 0.001$ was obtained, so the null hypothesis was rejected, in other words, not all means are equal. So the scores obtained by EI-DARL and Social Competence Test are related. The connections between the EI-DARL-V1 and the scales of Social Competence Test were checked. The correlation data are shown in Table 2.

As Table 2 shows, the combined emotional intelligence scale is significantly positively correlated with all of the joint social competence scale.

To evaluate the reliability of the measurement technique, the re-test method was used. Due to this reason, two EI measurements were performed fivesix weeks later in order to see how the respondents recognize the contents of the questions and if their answers remain unchanged during the period. The results of the first and second testing procedures were compared by using the Wilcoxon signed rank test. Hypotheses about the compatibility of the two measures were formed, i. e. if the statistical significance level $\mathrm{p} \leq 0.05$, then the hypothesis about the compatibility of the two measurements is rejected and the item of the difference between the two measurements is approved. By using the Wilcoxon signed rank test, it was found that neither

Table 2. Correlations (Spearman's correlation coefficient) between the EI-DARL-V1 and Social Competence Test scales

\begin{tabular}{|c|c|c|c|c|c|c|}
\hline \multirow[b]{2}{*}{$\begin{array}{l}\text { SOCIAL COMPETENCE } \\
\text { TEST SUBSCALES }\end{array}$} & \multicolumn{6}{|c|}{ THE SUB-SCALES OF THE EMOTIONAL INTELLIGENCE } \\
\hline & $\begin{array}{c}1 . \\
\text { "Emotion } \\
\text { perception" }\end{array}$ & $\begin{array}{c}2 . \\
\text { "Emotion } \\
\text { regulation" }\end{array}$ & $\begin{array}{c}3 . \\
\text { "Perception of } \\
\text { other's emotion" }\end{array}$ & $\begin{array}{c}4 . \\
\text { "Regulation of } \\
\text { other's emotion" }\end{array}$ & $\begin{array}{c}5 . \\
\text { "Manipu- } \\
\text { lations" }\end{array}$ & \begin{tabular}{|c|}
6. \\
Joint "Emotional \\
intelligence" scale
\end{tabular} \\
\hline $\begin{array}{l}\text { 1. "The general self- } \\
\text { confidence" }\end{array}$ & $\begin{array}{l}0.47 \\
* * *\end{array}$ & $\begin{array}{l}0.44 \\
* * *\end{array}$ & $\begin{array}{l}0.39 \\
* * *\end{array}$ & $\begin{array}{l}0.38 \\
* * *\end{array}$ & $\begin{array}{l}0.28 \\
* * *\end{array}$ & $\begin{array}{l}0.59 \\
* * *\end{array}$ \\
\hline $\begin{array}{l}\text { 2. "Resistance to } \\
\text { failures and critics" }\end{array}$ & $\begin{array}{l}0.42 \\
* * *\end{array}$ & $\begin{array}{l}0.43 \\
* * *\end{array}$ & $\begin{array}{l}0.19 \\
* * *\end{array}$ & $\begin{array}{l}0.24 \\
* * *\end{array}$ & 0.09 & $\begin{array}{l}0.47 \\
* * *\end{array}$ \\
\hline $\begin{array}{l}\text { 3. "The ability to } \\
\text { express feelings" }\end{array}$ & $\begin{array}{l}0.22 \\
* * *\end{array}$ & $\begin{array}{l}0.23 \\
* * *\end{array}$ & $\begin{array}{l}0.31 \\
* * *\end{array}$ & $\begin{array}{l}0.44 \\
* * *\end{array}$ & $\begin{array}{c}0.12 \\
*\end{array}$ & $\begin{array}{l}0.32 \\
* * *\end{array}$ \\
\hline $\begin{array}{l}\text { 4. "The ability to ask for } \\
\text { a favour" }\end{array}$ & $\begin{array}{l}0.39 \\
* * *\end{array}$ & $\begin{array}{l}0.32 \\
* * *\end{array}$ & $\begin{array}{l}0.24 \\
* * *\end{array}$ & $\begin{array}{l}0.32 \\
* * *\end{array}$ & 0.05 & $\begin{array}{l}0.38 \\
* * *\end{array}$ \\
\hline 5. "Noncompliance" & $\begin{array}{c}0.15 \\
*\end{array}$ & $\begin{array}{l}-0.12 \\
* *\end{array}$ & $\begin{array}{l}0.22 \\
* * *\end{array}$ & $\begin{array}{l}0.15 \\
* *\end{array}$ & $\begin{array}{l}0.28 \\
* * *\end{array}$ & $\begin{array}{c}0.15 \\
*\end{array}$ \\
\hline $\begin{array}{l}\text { 6. "The ability to } \\
\text { demand" }\end{array}$ & $\begin{array}{l}0.17 \\
* *\end{array}$ & $\begin{array}{c}0.17 \\
*\end{array}$ & $\begin{array}{l}0.16 \\
* *\end{array}$ & 0.09 & $\begin{array}{l}0.16 \\
* * *\end{array}$ & $\begin{array}{l}0.22 \\
* * *\end{array}$ \\
\hline 7. "Not feeling guilt" & $\begin{array}{l}0.28 \\
* * *\end{array}$ & $\begin{array}{l}0.22 \\
* * *\end{array}$ & 0.02 & -0.08 & 0.06 & $\begin{array}{l}0.26 \\
* * *\end{array}$ \\
\hline $\begin{array}{l}\text { 8. Joint "Social } \\
\text { competence" scale }\end{array}$ & $\begin{array}{l}0.40 \\
* * *\end{array}$ & $\begin{array}{l}0.35 \\
* * *\end{array}$ & $\begin{array}{l}0.29 \\
* * * \\
\end{array}$ & $\begin{array}{l}0.31 \\
* * *\end{array}$ & $\begin{array}{l}0.23 \\
* * *\end{array}$ & $\begin{array}{l}0.46 \\
* * *\end{array}$ \\
\hline
\end{tabular}


the overall evaluation of the first test or the re-test, nor the evaluations of both measures by separate scales satisfy the $p \leq 0.05$ condition, suggesting that there are no statistically significant differences between the measures. After conducting the retest, the results showed sufficient reliability of the methodology and the stability of the indicators: the obtained Spearman's correlation coefficients: $r=0.79$ of the joint EI-DARL-V1 test, $r=0.61$ of "Emotion perception", $r=0.58$ of "The understanding and control of other emotions" and $r=0.56$ of "Manipulations", $p \leq 0.05$ in all the cases. When assessing the reliability of the measurement technique using yet another - split-half method, the Spearman - Brown coefficient value for the whole measurement technique is high -0.88 .

\section{DISCUSSION}

A. Maul (2009) points out that despite the fairly long development of the EI theory, EI test validity and reliability issues remain ambiguous, i. e. the construction of the EI research instruments requires various methods to check these characteristics. According to M. Tavakol and R. Dennick (2011), reliability is closely related to validity. An instrument cannot be valid if it is not reliable. However, instrument reliability does not depend on validity. Thus, reliability is a necessary but not sufficient condition for validity; in addition, criterion-related validity research of the methodology can take plane only when the factorial validity of the methodology is proven (Gignac, 2009). The extraordinary importance of the factorization procedure was stressed by J. C. Nunnally (1978, pp. 112-113) stating that "... factor analysis is intimately involved with questions of validity; factor analysis is at the heart of the measurement of psychological constructs". Factor validity helps to answer the question "What does this test really measure?", and not "Does this test measure what it is supposed to measure?" (Gignac, 2009). Measuring factor reliability is very important to the EI research, since various EI models require narrower dimensions, such as perception of emotions, control of emotions, etc. Factor validity helps the researcher to determine which statements should be used to determine each scale. Thus, factor analysis on principle evaluates if the test is valid in a constructive sense. The inspection of the construct validity is especially important when it comes to such mental construct studies, which are characterized by theoretical concepts, in this case - EI. The authors of the measurement technique EI-DARL-V1 managed to create sufficiently high factorial loadings methodology $(0.71 \leq \mathrm{r} \leq 0.92)$, suggesting that the created categories are appropriate, the theoretical construct of EI is measured with sufficient precision and satisfies the construct validity methodological norm. However, it must be recognized that the authors sometimes manage to achieve even higher estimates, for example, the factorial weights of the EI measurement methodology MSCEIT, well-known in the academic environment, are $0.96 \leq \mathrm{r} \leq 0.98$ (Brackett, Mayer, 2003).

When the test is constructed in factorial principle, it is requested to check the criterion validity (Зеличенко, Шмелев, 1987). In this case, EI-DARL-V1 criterion concurrent validity was tested by choosing the results independent from the measurement technique, but related with the studied phenomenon - the Social Competence Test scales estimates as the validation criteria. As shown in the previous section, the constructed scale of the joint measurement technique is statistically significantly positively correlated with all the joint scale of the social competence. It is logical and theoretically significant that there is no statistical correlation between the understanding and control of other people's emotions and guilt. At the same time, there was no correlation detected between the "Manipulations" scale and the three social competence scales: "Resistance to failures and critics", "The ability to ask for a favour" and "Not feeling guilt". Negative statistical relationship was only found between the EI "Control of your own emotions" scale and the social competence "Noncompliance" scale.

As for the reliability of the measurement techniques (tests), the analysis of various sources has shown that the most recommended minimal test internal consistency estimate is 0.70 (Peterson, 1994). The values presented in this study fluctuate from 0.73 to 0.89 , so it can be stated that the measurement technique items correlate with each other sufficiently. Actually, similar estimates of these measurements are indicated by authors of other EI methods (e. g. internal consistency of the test TEIQue-ASF prepared by K. V. Petrides, Y. Sangareau, A. Furnham, N. Frederickson (2006) is 0.80). Some authors point out that the very high alpha coefficient (tending to 1.00) should not be the aim because it does not always 
mean a high degree of internal consistency. This is due to the fact that the coefficient is influenced by the length of the test. In other words, this means that in this case there are excess items which test the same question. Alpha value decreases when the test is shortened. M. Tavakol and R. Dennick (2011) recommended an alpha maximum of 0.90 , the limit which EI-DARL-V1 did not exceed. If the problem is opposite - you want to increase the coefficient - more items, testing the same concept, have to be added. It is important to mention that every time an empirical study is carried out, it should not rely on the Cronbach's alpha of specific methods published by authors, i. e. reliability should not be seen as a permanent feature of a test. Reliability should be interpreted as a feature of scores obtained during the testing; that is why it is recommended to measure the alpha in every case when the test is being administrated, since the value of the alpha varies depending on the testing conditions (Gignac, 2009; Tavakol, Dennick, 2011). Since the internal consistent reliability and retest reliability are not related to each other (Gignac, 2009), test-retest reliability of EI-DARL-V1 was checked; the results showed the sufficient reliability of the measurement technique and the stability of characteristics (see Results section). Some authors manage to get even higher retest estimates for the developed methodologies: the test-retest reliability of the full-test MSCEIT over a three-week interval was $r=0.86$ (Brackett, Mayer, 2003). When assessing the test in yet another - split-half - method, the value of the Spearman - Brown coefficient for the entire test is high -0.88 . By the way, this method only reaffirms the reliability of the test, even though it was tested on principle in analogous way - by estimating the Cronbach's alpha, which represents the average reliability of all possible split-halves (Cronbach, 1951). Other authors also get similar estimates by testing their created tests by using the split-half method (e. g. MSCEIT estimate is 0.93 (Brackett, Mayer, 2003)).

\section{CONCLUSIONS AND PERSPECTIVES}

1. In the absence of unanimous definition of EI while constructing the new original EI research methodology, it is reasonable, based on the best practices of foreign scientists, to integrate both major prevailing conceptions - treating the EI as both a personality trait and ability.

The created EI measurement technique EI-DARL has two forms - the short form (EIDARL-V1) and the long form (EI-DARLV2). The short version presented in this article consists of five scales ("Emotion perception", "Emotion regulation", "Perception of other's emotion", "Regulation of other's emotion" and "Manipulations"); it is a 73-item questionnaire, where the subjects reveal their degree of agreement with the items. The long version was supplemented by the scale of identification of nonverbal facial expressions and the scale of emotional, social and interpersonal situations.

2. The psychometric quality characteristics of the measurement technique meet the requirements: Cronbach's alpha coefficient values fluctuate from 0.73 to 0.89 ; the average inter-correlation among items is from 0.29 to $0.49 ; \mathrm{i} / \mathrm{tt}$ (resolution) indicators often exceed 0.5 ; the instrument has only those items, the factor weights of which exceed 0.3; factor's general explained dispersion ranges from $22 \%$ to $46 \%$; KMO values range from 0.88 to 0.94 . EI-DARL-V1 validity and reliability conditions are met.

It would be promising to explore more in detail the validity of the measurement technique EI-DARL-V1. For example, should the empathy scale be incorporated into the technology? It is not an easy question since there is no unanimous definition of EI, therefore further theoretical and empirical research of EI construct are needed.

Acknowledgement. The research has been supported by Research Council of Lithuania (Contract No. MIP-106/2012). 


\section{REFERENCES}

Borsboom, D. (2005). Measuring the Mind: Conceptual Issues in Contemporary Psychometrics. Cambridge: Cambridge University Press.

Brackett, M. A., Mayer, J. D. (2003). Convergent, discriminant and incremental validity of competing measures of emotional intelligence. Personality and Social Psychology Bulletin, 29, 1147-1158.

Brody, N. (2004). Emotional intelligence: Science and myth (book review). Personality and Individual Differences, 32, 109-111.

Cronbach, L. J. (1951). Coefficient alpha and the internal structure of tests. Psychometrika, 16, 297-334.

Gignac, G. E. (2009). Psychometrics and the measurement of emotional intelligence. In C. Stough et al. (Eds.), Assessing Emotional Intelligence, the Springer Series on Human Exceptionality (pp. 9-40). Springer Science Business Media, LLC.

Hunsley, J., Meyer, G. J. (2003). The incremental validity of psychological testing and assessment: Conceptual, methodological, and statistical issues. Psychological Assessment, 15, 446-455.

Lekavičienè, R., Antinienè, D. (2013). Emocinis intelektas: matavimo problemos ir galimybès. Šiuolaikinio specialisto kompetencijos: teorijos ir praktikos derme: 7-osios tarptautinès mokslinès-praktinès konferencijos straipsniu rinkinys (pp. 127-133). Kaunas: Kauno kolegija.

Lekavičienè, R., Antinienè, D. (2013). Studentu socialinès kompetencijos raiška ir dinamika: mokslo studija. Kaunas: Technologija.
Lekavičienè, R. (2001). Socialinès kompetencijos psichologiniai kriterijai ir vertinimas: monografija. Kaunas: VDU leidykla.

Maul, A. (2009). Improving the Measurement of Emotional Intelligence. American Psychological Association 2009 Convention: Abstracts. University Of California-Berkeley.

Nunnally, J. C. (1978). Psychometric Theory. New York: McGraw-Hill.

Peterson, R. A. (1994). A meta-analysis of Cronbach's alpha. Journal of Consumer Research, 21, 381-391.

Petrides, K. V., Sangareau, Y., Furnham, A., Frederickson, N. (2006). Trait emotional intelligence and children's peer relations at school. Social Development, 15, 537-547.

Schmidt, F. L., Hunter, J. E. (1999). Theory testing and measurement error. Intelligence, 27, 183-198.

Schutte, N. S., Malouff, J. M. (2012). Priming ability emotional intelligence. Intelligence, 40 (6), 614-621.

Sternberg, R. J., Grigorenko, E. L. (2007). Teaching for Successful Intelligence (2nd ed.). Thousand Oaks, CA: Corwin Press.

Tavakol, M., Dennick, R. (2011). Making sense of Cronbach's alpha. International Journal of Medical Education, 2, 53-55.

Зеличенко, А. И., Шмелев, А. Г. (1987). Психометрические основы психодиагностики. В кн. А. А. Бодалев, В. В. Столин (ред.), Общзая психодиагностика (сс. 53-112). Москва: Издательство Московского университета. 